九州大学学術情報リポジトリ

Kyushu University Institutional Repository

\title{
Some galatheids obtained from the Bonin Islands (Crustacea, Anomura)
}

Miyake, Sadayoshi

Zoological Laboratory, Department of Agriculture, Kyushu University

Baba, Ke i ji

Zoological Laboratory, Department of Agriculture, Kyushu University

https://doi.org/10.5109/22735

出版情報: 九州大学大学院農学研究院紀要. 13 (3)，pp.585-593，1965-05. Kyushu University バージョン：

権利関係 : 
Journal of the Faculty of Agriculture, Kyushu University, Vol. 13, No. 3

May 30, 1965

Some galatheids obtained from the Bonin Islands

(Crustacea, Anomura)*

Sadayoshi Miyake and Keiji Baba

This paper is the description of the genus Galathea belonging to the family Galatheidae collected from the Bonin Islands (Ogasawara Islands) by the late Dr. Hayato Ikeda who had been one of the staffs in our laboratory. His collection of this genus consists of three species, such as Galathea boninensis sp. nov., G. ikedai sp. nov. and G. serrirostris Melin.

\section{Galathea boninensis sp. nov.}

(Figs. 1, 2)

Holotype, male, Cat. No. 4885, Zoological Laboratory, Faculty of Agriculture, Kyushu University ; near Muko-jima. Bonin Islands ; July 18-19, 1938.

Carapace nearly as long as broad excluding rostrum. The striation weak and provided with the usual fringe of fine setae which are mostly short, and sparsely provided with long setae, especially on the lateral margins. Number and arrangement of the transverse ridges as represented in Fig. 1. No spines on the gastric region.

Rostrum as long as broad, armed on each side with four teeth, of which the fourth is quite small and the others are rather large. The dorsal surface pubescent. A long seta springs from each angle between the rostral teeth. The external orbital angle rounded and unarmed. Behind this carapace armed with seven teeth, of which the second is small and supplementary, and slightly dorsal in position. Immediately behind the insertion of the antenna there are a well developed and a small spine, and they are not seen from a dorsal view.

* Contributions from the Zoological Laboratory, Faculty of Agriculture, Kyushu University, No. 333. 
The anterior part of sternal segments as represented in Fig. 2, D . The basal segment of the antennular peduncle armed with three forwardly directed spines on its distal margin, one of them terminates

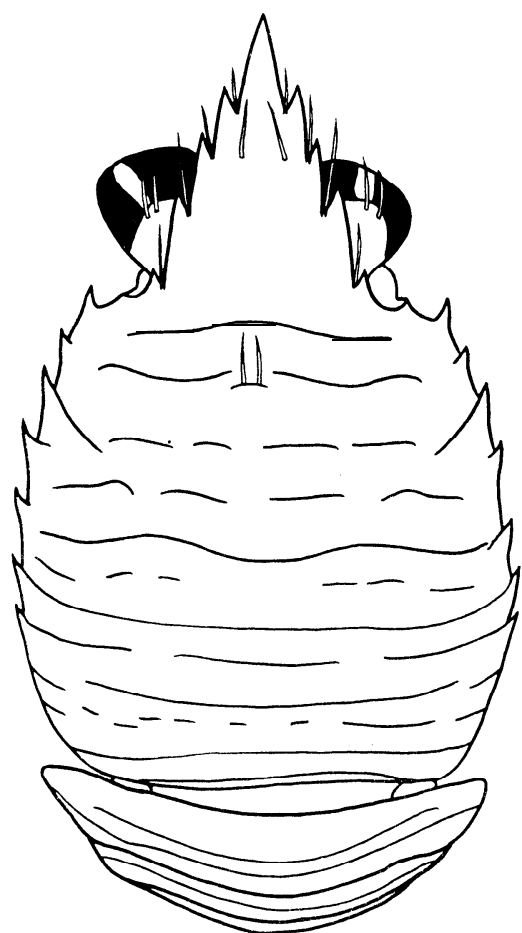

Fig. 1. Galathea boninensis sp. nov., holotype, male, in dorsal view, $\mathrm{x} 12$

upper surface while the other two are rather small on the outer, and well developed and sharp on the inner margin. The lower surface of the wrist, palm and movable finger not spinose, but that of the arm furnished with a few spinules. The movable finger is rather less than twice as long as the palm, and has only two spines at its tip. The fingers not gapped.

Ambulatory legs have few setae but rather thick hairs along the outer margin of the merus. The first and second pairs of ambulatory legs armed with a row of spines along the outer margin of the merus, carpus and proximal half of the propodus. A secondary row of spines lies to the outer side of the marginal carpal row. Number and arrangement of these spines as represented in Fig. 6, F-G. There are also spines on the inner margin of the propodus, which are slender, 
elongated and directed forwardly. In the third ambulatory legs the armature is not so much emphasized. The dactylus of each ambulatory leg has six serrated teeth along the inner margin, and from the base of each tooth a large seta springs.

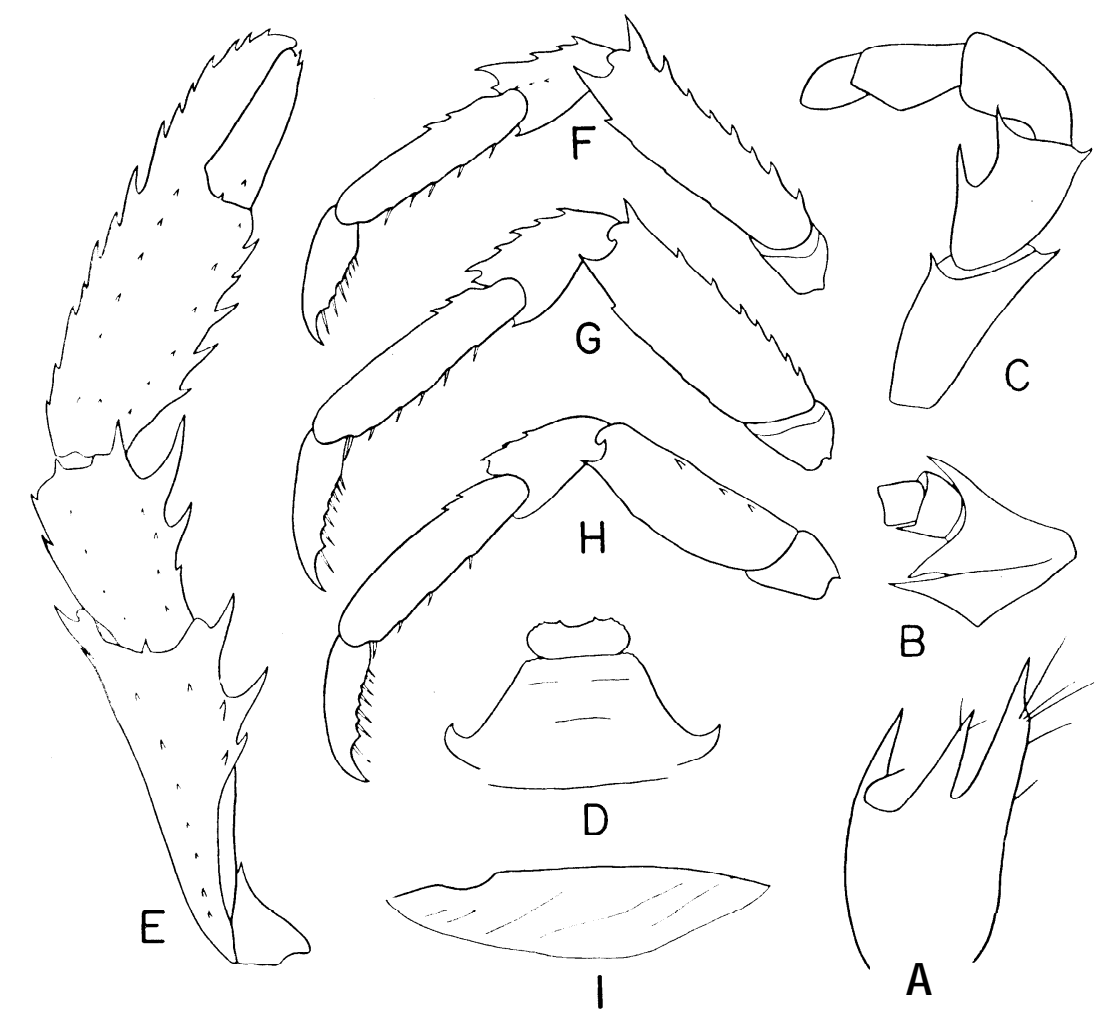

Fig. 2. Galatheaboninensis sp. nov., holotype, male. A. basal segment of left antennule, $\times 24$; B. left antennal peduncle, $x 24$; . endopod of left third maxilliped, x24; D. anterior part of sternal segments, $\mathrm{x} 16$; E. left cheliped, $\times 12$; F. left first ambulatory leg, x 12; G. left second ambulatory leg, $x$ 12; H. left third ambulatory leg, $\mathrm{x} 12$; I. left pterygostomial flap, $\times 12$.

Dimensions (in $\mathrm{mm}$ ):

Length of carapace including rostrum .................... 6.50

Breadth of carapace ....................................... 3.95

Length of rostrum ...................................... 2.30

Breadth of rostrum .......................................... 1.60

Length of cheliped ....................................... 11.35

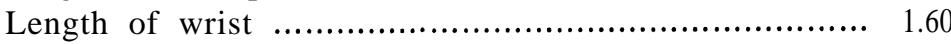


Breadth of wrist .................................................. 1.20

Length of palm ................................................. $\quad 2.90$

Breadth of palm ................................................. 1.25

Length of movable finger ...................................... 1.95

Remarks. This is very similar to G. latirostris Dana and G. platycheles Miyake in the armature of the carapace, but it is easily distinguished from the former by lacking the second supplementary small spine on the lateral margin of the carapace and by the number of inner marginal spines of the third maxilliped. From the latter it is also distinguished by having setae at angles between the rostral teeth

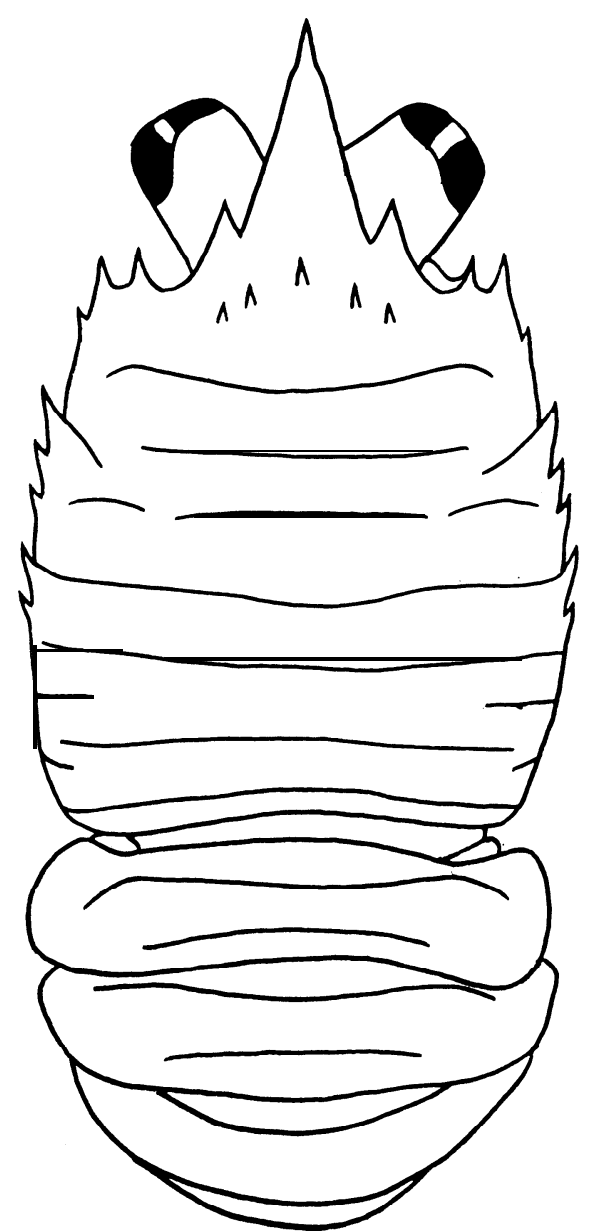

Fig. 3. Galathea ikedai sp. nov., holotype, ovigerous female, in dorsal view, $x 23$. and by having a spine which forms the external angle of the orbit.

\section{Galathea ikedai sp. nov. \\ (Figs. 3, 4)}

Holotype, ovigerous female, Cat. No. 4886, Zoological Laboratory, Faculty of Agriculture, Kyushu University ; near Mukojima, Bonin Islands; July 18-19, 1938.

Carapace longer than broad excluding rostrum. The striation weak and provided with fine setae. The gastric region not well defined, and five spines stand on the anterior part. Rostrum longer than broad. The lateral margin not toothed, but has a well developed tooth at the base of each side.

The outer orbital angle is a sharp tooth. Behind it the carapace armed with six marginal spines, of which the first is the largest and the second is slightly dorsal in position. No tooth immediately behind the insertion of the antenna.

The basal segment of the antennule bears on its distal 
margin four forwardly directed spines. The anterior prolongation of the first segment of the antennal peduncle reaches to the middle of the rostrum; the second segment armed with spines on both inner and outer distal margins ; and the third segment with an inner distal spine.

The ischium of the third maxilliped longer than the merus, and its inner toothed ridge has about 23 closely placed denticles. The merus has a minute tooth on its outer distal margin, and with the inner margin bispinose.
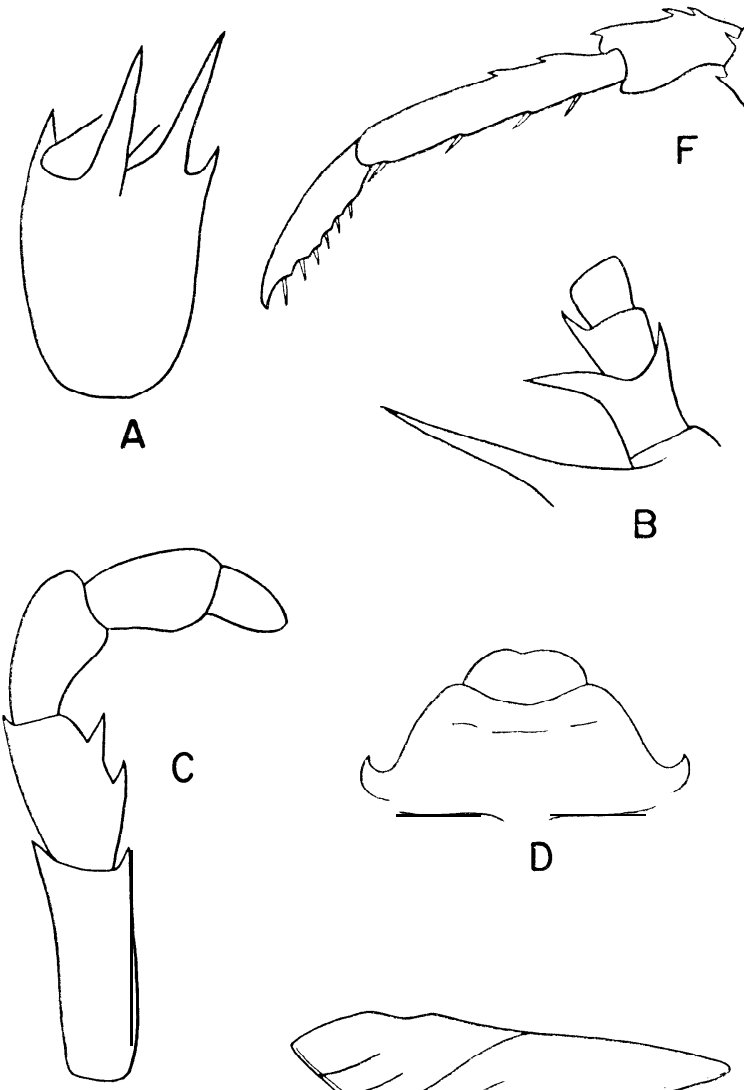

G

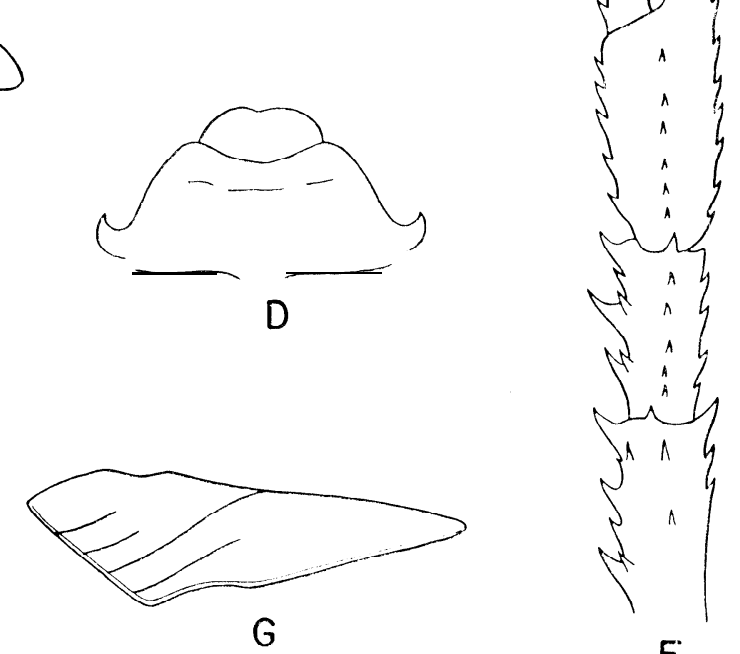

B

$E$

Fig. 4. Galathea ikedai sp. nov., holotype, ovigerous female. A. basal segment of left antennule, $x 42$; B. left antenna1 peduncle, $\mathrm{x} 42$; C. endopod of right third maxilliped, $x$ 30; D. anterior part of sternal segments, $x 42 ; \quad$ E. right cheliped, $x 16$; F. left ambulatory leg, $\times 16$; G. left pterygostomial flap, $\times 20$. 
The cheliped furnished with few setae. The wrist four-fifths the length of the movable finger, and furnished with three large spines on the inner margin, four spines on the outer margin and two longitudinal rows of spines on the upper surface. The palm about as long as the movable finger, furnished with spines on both lateral margins. A longitudinal row of spines on the upper surface of the palm. The fingers slightly gapped. The movable finger armed with two large tubercles on the cutting margin, and one spine at the base of the inner margin. Immovable finger has a large tubercles near the base of the cutting margin.

Only one ambulatory leg remains and has detached from the body. There are eight spines on the outer margin of the merus, three spines on that of the carpus, two on the outer margin of the propodus, four elongated and forwardly directed spines on the inner margin of the propodus. The inner margin of the dactylus has six weakly serrated teeth, and from the base of each a large seta springs.

\begin{tabular}{|c|c|}
\hline Length of carapace including rostrum & 3.40 \\
\hline Breadth of carapace & 2.25 \\
\hline Length of rostrum & 0.95 \\
\hline Breadth of rostrum & 0.55 \\
\hline Length of cheliped & 7.30 \\
\hline Length of wrist ..... & 1.05 \\
\hline Breadth of wrist & 0.55 \\
\hline Length of palm.. & 1.40 \\
\hline Breadth of palm & 0.80 \\
\hline I onoth of & 1.60 \\
\hline
\end{tabular}

Remarks. This specimen is very similar to G. pusilla Henderson, from which it differs in the following respects. (1) A row of five gastric spines. (2) The merus of the third maxilliped has two spines on the inner margin, and its outer distal angle is not so developed as in G. pusilla.

\section{Galathea serrirostris Melin}

(Figs. 5, 6)

Galathe a serrirostris Melin, 1939, pp. 72-77, figs. 43-47-Port Lloyd (=Futami); Tokinoura (=? Takinoura) ; Hatsume (=? Hatsune) ; east of Chichi-jima, Bonin Islands.

Material examined. 1 ovig. 우, Cat. No. 4887, Zoological Laboratory, Faculty of Agriculture, Kyushu University ; near Muko-jima, Bonin Islands ; July 18-19, 1938.

Carapace nearly as long as broad excluding rostrum. There are 
two spines on the first stria in front of the gastric region.

Rostrum slightly longer than broad. The lateral margin not toothed except a rather large one at the base, but slightly notched near the distal margins. The upper surface of the rostrum smooth and not setose. The outer orbital angle sharped and pyramid-like. Behind this the carapace armed with!seven spines on the lateral margin, of which the first is the largest, and the second is quite small and slightly dorsal in position. No spines behind the insertion of the antenna.

The form of the anterior sternal segments as represented in Fig. 5, D. On the distal margin the basal segment of the antennule bears five spines, one of which extends to the shallow notch of the rostrum.

The ischium of the third maxilliped longer than the merus, and furnished with a small spine on its inner distal margin. On the median part of the inner margin the merus has a sharped tooth, and armed with an outer marginal spine being well developed and directed slightly inwards.

The cheliped not thickly setose. The movable finger about half the length of the palm, and armed with two spinules on the outer margin. The palm has a row of well developed spines on the inner margin and two rows of spinules on the upper surface.

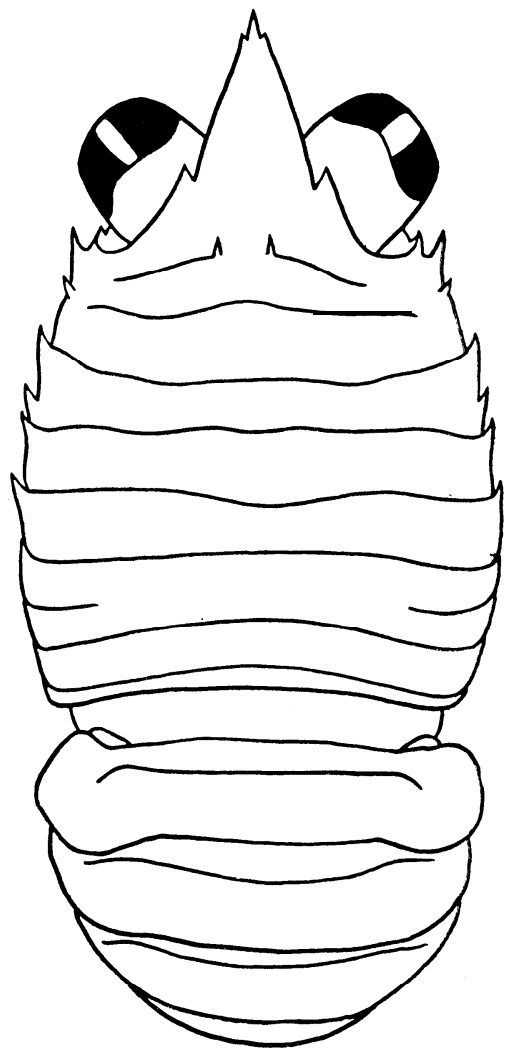

Fig. 5. Galathea serrirostris Melin, in dorsal view, x28.

Dimensions (in $\mathrm{mm}$ ) :

Length of carapace including rostrum ..................... 2.50

Breadth of carapace ...................................... 1.95

Length of rostrum ..................................... 0.65

Breadth of rostrum ........................................... 0.45

Length of cheliped ......................................... 5.25

Length of wrist .......................................... 0.85

Breadth of wrist .............................................. 0.35

Length of palm ......................................... 1.20 
Breadth of palm .............................................. 0.45

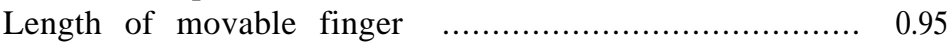
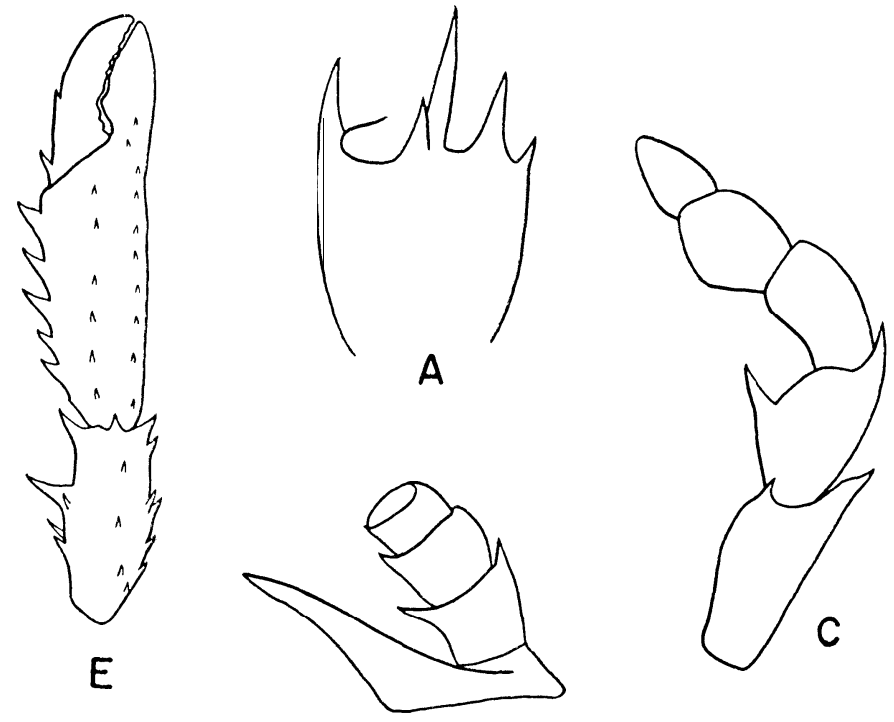

B

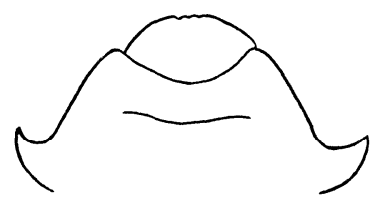

D

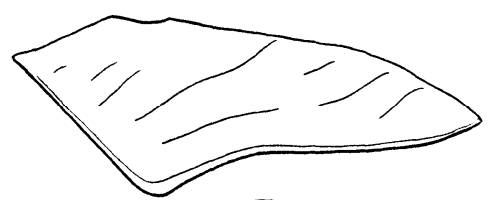

$F$

Fig. 6. Galathea serrirostris Melin. A. basal segment of left antennule, x60; B. left antenna1 peduncle, x 60; C. endopod of left third maxilliped, x 30 ; D. anterior part of sternal segments, $x \quad 40$; E. right cheliped, x 20 ; F. left pterygostomial flap, x30.

Remarks. This specimen agrees with G. serrirostris Melin with the exception that the lateral margin of the rostrum is not serrated as stated in the original description, and with the exception of the form of the anterior prolongation of the first segment of the antennal peduncle. On the other hand, this specimen is closely allied to G. pusilla Henderson in all appearance of the carapace, in the form of the antennule and in the form of the merus of the third maxilliped, from which it is distinguished by the following respects. (1) The gastric region has two spines. (2) The sternum of the third thoracic somite is not oblong in comparison with G. pusilla collected from Sagami Bay, Japan. 


\section{REFERENCE}

Benedict, J. E. 1902. Descriptions of a new genus and forty-six new species of crustaceans of the family Galatheidae, with a list of the known marine species. Proc. U. S. Nat. Mus., vol. 26, no. 1311, pp. 243-334.

Dana, J. D. 1852. Crustacea.-United States Exploring Expedition during the year 1838-1843, . Philadelphia, vol. 13, pp. 1-685.

Henderson, J. R. 1885. Diagnoses of the new species of Galatheidea collected during the 'Challenger' Expedition. Ann. Mag. Nat. Hist., ser. 6, vol. 8, pp. 407-421.

1888. Report on the scientific results of the Voyage of H. M. S. Challenger, Zool., vol. 27, Anomura, pp. 1-221, pls. 1-21.

Laurie, R. D. 1926. Anomura collected by Mr. J. Stanley Gardiner in the Western Indian Ocean in H. M. S. "Sealark." Trans. Linn. Soc., London, ser. 2, Zool., vol. 19, pt. 1, pp. 121-167.

Melin, G. 1939. Paguriden und Galatheiden von Prof. Dr. Sixten Bocks Expedition nach den Bonin-Inseln 1914. Kungl. Svenska Vetensk.-akad. Handl., Stockholm, ser. 3, no. 2, pp. 1-119.

Miyake, S. 1953. On three new species of Galathea from the Western Pacific. J. Fac. Agric., Kyushu Univ., vol. 10, no. 2, pp. 199-208.

Yokoya, Y. 1933. On the distribution of decapod crustaceans inhabiting the continental shelf around Japan, chiefly based upon the materials collected by S. S. Soyo-maru during the year 1923-1930. J. Coll. Agric., Tokyo Imp. Univ., vol. 12, no. 1, pp. 1-226. 